\title{
The influence of the post-processing method on knoop hardness of photosensitive resins for 3D SLA printer used in Dentistry
}

- Mayra Torres Vasques Department of Prosthodontics, School of Dentistry, University of São Paulo, São Paulo, São Paulo, Brazil • Júlia Nascimento da Silva Mulder Department of Prosthodontics, School of Dentistry, University of São Paulo, São Paulo, São Paulo, Brazil • Débora Santos Machado School of Dentistry, University of São Paulo, São Paulo, São Paulo, Brazil - Dalva Cruz Laganá Department of Prosthodontics, School of Dentistry, University of São Paulo, São Paulo, São Paulo, Brazil

ABSTRACT | Objectives: The aim of this study is to compare the mechanical characteristics of resins for 3D printers with the acrylic resins that have been used in Dentistry, according to the post-processing method. Materials and Methods: Using an SLA 3D printer (Form 2 - Formlabs, Massachusetts, USA), samples (discs) were produced with the printer's resins, Dental $\mathrm{SG}^{\circledR}$, Dental $\mathrm{LT}^{\circledR}$, Clear ${ }^{\circledR}$. Samples made of thermopolimerized and auto polymerized acrylic resins were produced as well (Gold Standart parameters). The Knoop Hardness (KH) tests were performed using microdurometer HMV-2 (Shimadzu, Kyoto, Japan). Results: The results showed the Dental SG resin presented the highest $\mathrm{KH}$, compared with thermopolimerized acrylic resin, the Clear and Dental LT resins KH were compared with auto polymerized acrylic resin, and the non-post cured Dental LT resin showed the lowest KH. Conclusions: Considering the hardness, the printer's resins are comparable with the acrylic resins established, when the post-processing method is thoroughly followed. The absence of material's post-processing reduce significantly the material's hardness. Clinical relevance: Regarding the use of $3 \mathrm{D}$ printing in Dentistry, the development of materials adequate for the equipment, biocompatible for intraoral uses, and compatible mechanical proprieties are essential.

DESCRIPTORS | Digital Dentistry; Polymers; Hardness Knoop; CAD/CAM; Additive Manufacturing; Dental Resin.

RESUMO | Influência do método de pós-processamento na dureza Knoop de resinas fotossensíveis para impressoras 3D SLA usadas na Odontologia - Objetivos: O objetivo deste estudo é comparar as características mecânicas das resinas para impressoras 3D com as resinas acrílicas utilizadas em Odontologia, de acordo com o método de pós-processamento. Materiais e Métodos: Utilizando uma impressora SLA 3D (Form2 - Formlabs, Massachusetts, EUA), amostras (discos) foram produzidas com as resinas da impressora, Dental SG${ }^{\circledR}$, Dental LT $^{\circledR}$, Clear ${ }^{\circledR}$. Também foram produzidas amostras feitas de resinas acrílicas termopolimerizadas e autopolimerizadas (parâmetros Gold Standart). Os testes de dureza Knoop (KH) foram realizados usando o microdurômetro HMV-2 (Shimadzu, Kyoto, Japão). Resultados: Os resultados mostraram que a resina Dental SG apresentou o KH mais alto, em comparação com a resina acrílica termopolimerizada, as resinas Clear e Dental LT KH foram comparadas com a resina acrílica autopolimerizada e a resina sem pós-cura Dental LT apresentou o menor KH. Conclusões: Considerando a dureza, as resinas da impressora são comparáveis às resinas acrílicas, quando o método de pós-processamento é completamente seguido. A ausência do pós-processamento do material reduz significativamente a dureza do material. Relevância clínica: No que diz respeito ao uso da impressão 3D em Odontologia, o desenvolvimento de materiais adequados ao equipamento, biocompatíveis para usos intraorais e propriedades mecânicas compatíveis é essencial.

DESCRITORES | Odontologia Digital; Polímeros; Dureza Knoop; CAD-CAM; Manufatura Aditiva; Resina Dental.

CORRESPONDING AUTHOR | Mayra Torres Vasques Department of Prosthodontics, School of Dentistry, University of São Paulo • Avenida Pavão, 955 room 52 • São Paulo, SP, Brazil • 04516-012 •E-mail: mtvasques@usp.br

- Received Aug. 21, 2019 • Accepted Oct. 23, 2019

- Dol http://dx.doi.org/10.11606/issn.2357-8041.clrd.2019.161294 


\section{INTRODUCTION}

The advent of three-dimensional printers with the stereolithography additive manufacture (SLA) technique and the possibility of its use in the healthcare field led to the development of specific photosensitive and biocompatible resins (3DR), particularly for Dentistry. ${ }^{1}$

The advantages of $3 \mathrm{D}$ printing include the possibility of producing customized appliances, in an easier and faster process, high accuracy, and the possibility of reproducing the same object multiple times, if necessary. ${ }^{2}$

The professionals must understand the development of the new material and its indications and characteristics to obtain the best and safest treatment results, considering the increasing number of studies about materials for CAD/CAM use in Dentistry.3.4

The acrylic resins (AR) have been used in Dentistry for a long time to produce dental restorations, prosthesis, and models, and its characteristics, proprieties, and indications are well known; they are considered the gold-standart materials. ${ }^{5}$

Despite the material's components of $3 \mathrm{DR}$ being similar to AR (Table 1), there are differences regarding the components of $3 \mathrm{DR}$ and the photoinitiators and the different degree of material conversion that could lead to different mechanical proprieties..$^{6,7,8,9}$

TABLE 1 | Resins' Composition.

\begin{tabular}{l|l}
\multicolumn{1}{c|}{ Resin } & \multicolumn{1}{c}{ Composition } \\
\hline Thermo polymerized & \\
\hline Auto polymerized & $\begin{array}{l}\text { powder: pre-polymerized methyl spheres (methyl methacrylate), benzoyl peroxide (initiator) } \\
\text { Liquid: unpolymerized methyl methacrylate, hydroquinone (inhibitor). }\end{array}$ \\
\hline Dental SG & $\begin{array}{l}\text { powder: poly (methyl methacrylate), benzoyl peroxide (initiator) } \\
\text { Liquid: unpolymerized methyl methacrylate, hydroquinone (inhibitor) and tertiary amine. }\end{array}$ \\
\hline Dental LT & $\begin{array}{l}\text { Methacrylate oligomers; } \\
\text { Phosphine oxides }\end{array}$ \\
\hline Clear & Methacrylic oligomer; Glycol Methacrylate; Phosphine oxide; Pentamethyl-piperidy sebacate \\
\hline
\end{tabular}

One of the important mechanical proprieties of the resins is their hardness, which elucidates its capacity to resist to wear and deformation. The Knoop hardness test is a test of mechanical microhardness of the materials, in which an indentation is made on the tested material surface pressing (loading) a diamond in a pyramidal form over it. The geometry of the indentation is measured using a microscope, and the data are analyzed using the Knoop Hardness formula. ${ }^{10,11}$

Considering some of the resins for $3 \mathrm{D}$ SLA printers (3DR) available in the Dentistry field, the aim of this study was to evaluate the Knoop Hardness of the new resins and compare it with the thermo and autopolymerized acrylic resins.

\section{MATERIALS AND METHODS}

\section{SAMPLE MANUFACTURE}

Using an SLA 3D printer, Form2 (Formlabs, Massachusetts, USA), discs $(n=3)$ of the resins Dental SG, Clear and Dental LT were manufactured; the printing layer thickness was $0.1 \mathrm{~mm}$ and the disc dimensions were $30 \mathrm{~mm}$ diameter x $2.5 \mathrm{~mm}$ thickness. After the printing process, the discs were post-processed (cleaned and cured) according to the manufacturer guidelines (Table 2), except for the samples of the Dental LT resin that presents one group of cured and non-cured samples. Samples $(n=3)$ of the thermopolymerized and autopolymerized acrylic resins were manufactured in a laboratory. 
TABLE 2 | 3D Resins post-processing protocols, following the manufacturer recommendations.

\begin{tabular}{|c|c|c|}
\hline RESIN & WASHING PROCESS & CURING PROCESS \\
\hline Dental SG & Rinse in isopropyl alcohol (IPA, 96 percent or higher) for 5 minutes. & $\begin{array}{l}\text { Exposure for } 30 \text { minutes to } 108 \text { watts each of Blue UV-A } \\
(315 \mathrm{~nm}-400 \mathrm{~nm}) \text { and UV-B } \\
(400 \mathrm{~nm}-550 \mathrm{~nm}) \text { light, in a heated environment at } 60{ }^{\circ} \mathrm{C} \text {. }\end{array}$ \\
\hline Dental LT & $\begin{array}{l}\text { Rinse in isopropyl alcohol (IPA, } 96 \text { percent or higher) for } 5 \text { minutes. } \\
\text { Do not leave parts in alcohol for more than } 10 \text { minutes }\end{array}$ & $\begin{array}{l}\text { Exposure for } 20 \text { minutes to } 108 \text { watts each of Blue UV-A } \\
(315 \mathrm{~nm}-400 \mathrm{~nm}) \text { and UV-B } \\
(400 \mathrm{~nm}-550 \mathrm{~nm}) \text { light, in a heated environment at } 80{ }^{\circ} \mathrm{C} \text {. }\end{array}$ \\
\hline Clear & Rinse in isopropyl alcohol (IPA, 96 percent or higher) for 10 minutes & $\begin{array}{l}\text { Exposure for } 30 \text { minutes to } 108 \text { watts each of Blue UV-A } \\
(315 \mathrm{~nm}-400 \mathrm{~nm}) \text { and UV-B } \\
(400 \mathrm{~nm}-550 \mathrm{~nm}) \text { light, in a heated environment at } 60{ }^{\circ} \mathrm{C} \text {. }\end{array}$ \\
\hline
\end{tabular}

\section{KNOOP HARDNESS (KH) TEST}

The discs were polished in a polishing machine (Buehler Automet 250 - Buehler, Coventry, Great Britain) to prepare the samples for the $\mathrm{KH}$ test, using silicon carbide sandpapers with the granulations 220, 320, 500, 1200 during 2 minutes each and finalizing with granulation 2000 during 2.5 minutes, the applied force was $20 \mathrm{~N}$, there was water irrigation during all the polishing process.

After polishing the discs, they were submerged in distilled water during $24 \mathrm{~h}$ to hydrate the samples, simulating the materials' intraoral conditions.

The hydrated discs were tested in the microdurometer HMV-2 (Shimadzu, Kyoto, Japan) using CAMPS program, which was calibrated to load the surface of the samples with 25 grams for 10 seconds. Five indentations were performed in each sample $(500 \mu \mathrm{m}$ distant from each other and from specimen's boards). The indentations were analyzed using an optical microscopy and 10 magnification lens and measured following the Knoop hardness formula: $\mathrm{HK}=14,229 \mathrm{X}\left(\mathrm{P} / \mathrm{L}^{2}\right)$ (where $\mathrm{P}$ is the load and $\mathrm{L}$ is the length of the long axis of the indentation). ${ }^{10}$

\section{STATISTICAL ANALYSIS}

For multiple comparisons between the resins, we used the ANOVA test, followed by Tukey's test. The significance level was set at $5 \%$.

\section{RESULTS}

Table 3 shows the values found during the KH test:

Data statistical analysis was performed using the website http://vassarstats.net/anova1u.html. Significance was verified in the variation of the average values of the Knoop hardness through the ANOVA statistical test followed by the Tukey's test.

TABLE 3 | KH values per sample $(n=5)$ in the different resins tested.

\begin{tabular}{|c|c|c|c|c|c|}
\hline \multicolumn{2}{|c|}{ CLEAR } & \multicolumn{2}{|c|}{ DENTAL SG (CURED) } & \multicolumn{2}{|c|}{ DENTAL LT (NOT CURED) } \\
\hline & $\mathrm{KH}$ & & $\mathrm{KH}$ & & $\mathrm{KH}$ \\
\hline \multirow[t]{5}{*}{1} & 12.8 & 1 & 18.8 & 1 & 5.6 \\
\hline & 12.8 & & 18.5 & & 5.4 \\
\hline & 13.4 & & 18.7 & & 5.5 \\
\hline & 13.1 & & 18.2 & & 5.0 \\
\hline & 13.9 & & 18.3 & & 5.7 \\
\hline \multirow[t]{3}{*}{2} & 12.3 & 2 & 18.8 & 2 & 5.0 \\
\hline & 12.6 & & 18.1 & & 5.6 \\
\hline & 12.2 & & 18.0 & & 4.9 \\
\hline
\end{tabular}


TABLE 3 | Continuation

\begin{tabular}{|c|c|c|c|c|c|}
\hline \multicolumn{2}{|c|}{ CLEAR } & \multicolumn{2}{|c|}{ DENTAL SG (CURED) } & \multicolumn{2}{|c|}{ DENTAL LT (NOT CURED) } \\
\hline & 11.2 & & 18.9 & & 5.3 \\
\hline & 12.3 & & 18.5 & & 5.4 \\
\hline \multirow[t]{5}{*}{3} & 13.4 & 3 & 19.9 & 3 & 5.0 \\
\hline & 13.2 & & 18.7 & & 5.7 \\
\hline & 13,6 & & 18.5 & & 5.1 \\
\hline & 13.9 & & 19.2 & & 5.2 \\
\hline & 13.4 & & 19.5 & & 5.5 \\
\hline Minimum & 11.2 & Minimum & 18.0 & Minimum & 4.9 \\
\hline Maximum & 13.9 & Maximum & 19.9 & Maximum & 5.7 \\
\hline Mean & 12.94 & Mean & 18.707 & Mean & 5.327 \\
\hline SD & 0.735 & SD & 0.519 & SD & 0.276 \\
\hline \multicolumn{2}{|c|}{ DENTAL LT (CURED) } & \multicolumn{2}{|c|}{ AUTOPOLYMERIZED } & \multicolumn{2}{|c|}{ THERMO POLYMERIZED } \\
\hline & $\mathrm{KH}$ & & $\mathrm{KH}$ & & $\mathrm{KH}$ \\
\hline \multirow[t]{5}{*}{1} & 12.8 & 1 & 9.0 & 1 & 13.6 \\
\hline & 14.8 & & 8.4 & & 13.4 \\
\hline & 13.7 & & 9.2 & & 14.1 \\
\hline & 10.4 & & 8.5 & & 14.4 \\
\hline & 10.3 & & 8.9 & & 14.4 \\
\hline \multirow[t]{5}{*}{2} & 10.6 & 2 & 11.0 & 2 & 19.0 \\
\hline & 12.8 & & 12.0 & & 17.9 \\
\hline & 12.3 & & 11.4 & & 19.2 \\
\hline & 10.6 & & 12.6 & & 19.8 \\
\hline & 10.7 & & 11.7 & & 19.5 \\
\hline \multirow[t]{5}{*}{3} & 12.0 & 3 & 11.5 & 3 & 15.8 \\
\hline & 11.5 & & 11.4 & & 17.2 \\
\hline & 12,2 & & 12.5 & & 16.0 \\
\hline & 11.6 & & 12.2 & & 16.9 \\
\hline & 11.6 & & 11.5 & & 17.4 \\
\hline Minimum & 10.3 & Minimum & 12.6 & Minimum & 13.4 \\
\hline Maximum & 14.8 & Maximum & 8.4 & Maximum & 19.8 \\
\hline Mean & 11.86 & Mean & 10.787 & Mean & 16.573 \\
\hline $\mathrm{SD}$ & 1,295 & SD & 1.524 & SD & 2.238 \\
\hline
\end{tabular}

\section{RESINS FOR INTRAORAL USE}

Table 4 shows the comparative analysis summary, considering the resins used with intraoral propose and those to manufacture dental appliances (Thermo polymerized, Autopolymerized, Dental SG, Dental LT) and the Clear resin; Table 5 shows the data of the ANOVA test and Table 6 the result of the Tukey's test for the same resins. Graph 1 shows the KH mean value of each resin. 
TABLE 4 | Summary Statistical Analysis of the intraoral uses' resins.

\begin{tabular}{l|c|c|c|c|c|c} 
& $\begin{array}{c}\text { Thermo } \\
\text { polymerized M1 }\end{array}$ & $\begin{array}{c}\text { Autopolymerized } \\
\text { M2 }\end{array}$ & Dental SG M3 & $\begin{array}{c}\text { Dental LT (cured) } \\
\text { M4 }\end{array}$ & Clear M5 & Total \\
\hline $\mathrm{N}$ & 15 & 15 & 15 & 15 & 15 \\
\hline$\Sigma \mathrm{x}$ & 248.6 & 161.8 & 208.6 & 177.9 & 194.1 & 1063 \\
\hline Mean & 16.5733 & 10.7867 & 18.7067 & 11.86 & 12.94 & 14.1733 \\
\hline$\sum \times 2$ & 4190.24 & 1777.82 & 5252.86 & 2133.37 & 2519.21 & 15873.5 \\
\hline Variance & 5.0078 & 2.3241 & 0.2692 & 1.6769 & 0.5397 & 10.9087 \\
\hline Std. Dev & 2.2378 & 1.5245 & 0.5189 & 1.2949 & 0.7347 & 3.3028 \\
\hline Std. Err. & 0.5778 & 0.3936 & 0.134 & 0.3344 & 0.1897 & 0.3814 \\
\hline
\end{tabular}

TABLE 5 | Data Summary for ANOVA test of intraoral resins.

\begin{tabular}{l|c|c|c|c|c}
\multicolumn{5}{|c}{ ANOVA Summary } \\
\hline Source & SS & df & MS & F \\
\hline Treatment (between groups) & 669.7987 & 4 & 167.4497 & 85.28 & $<.0001$ \\
\hline Error & 137.448 & 70 & 1.9635 & & \\
\hline Total & 807.2472 & 74 & & \\
\hline
\end{tabular}

TABLE 6 | Tukey's test results of intraoral resin.

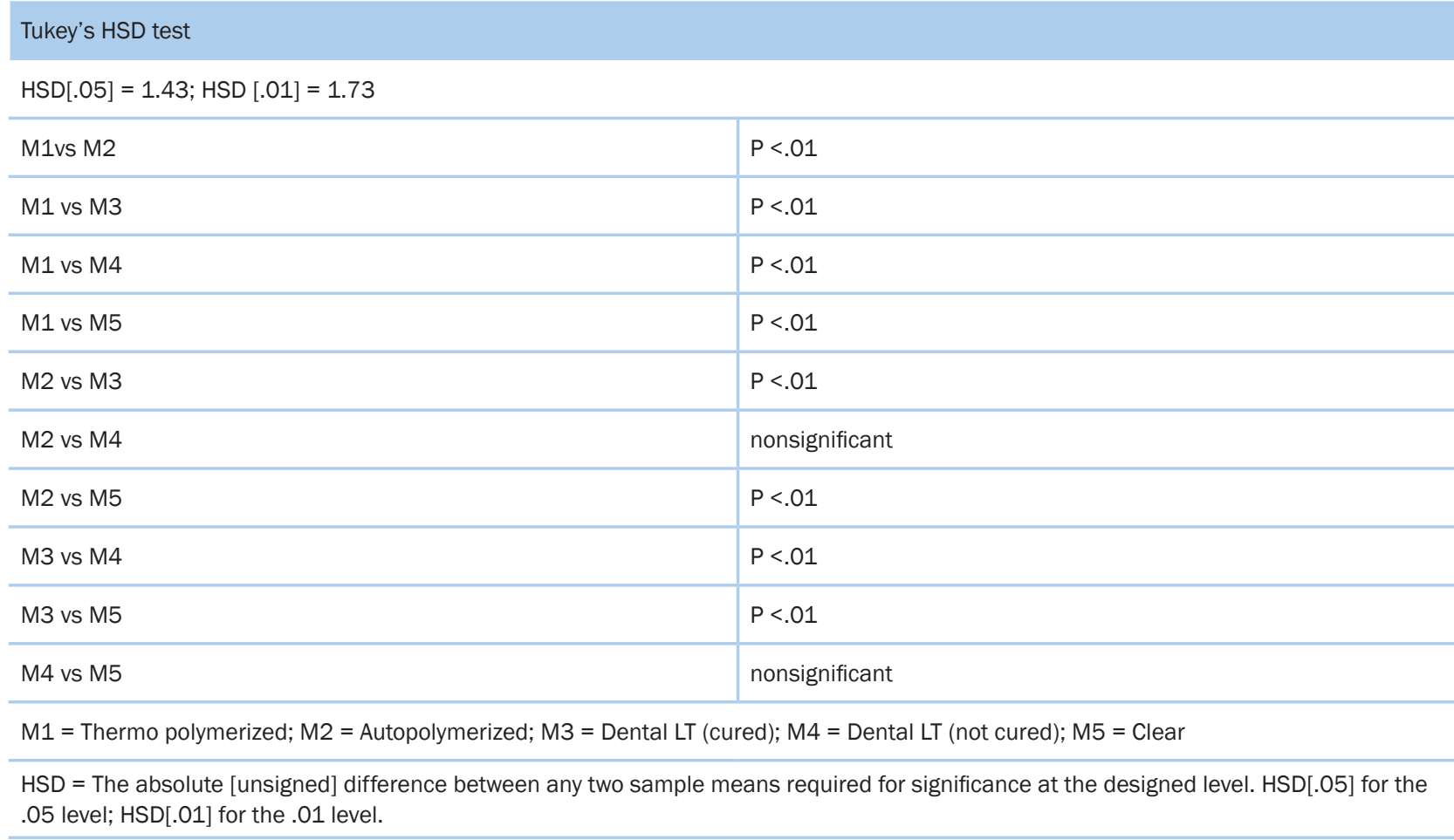


GRAPH 1 | KH Mean values of the resins for intraoral uses, standard deviation and significance (groups identified by the same letter there was nonsignificant: (a) - autopolimerized and dental LT (cured) and (b) - dental LT (cured) and Clear)

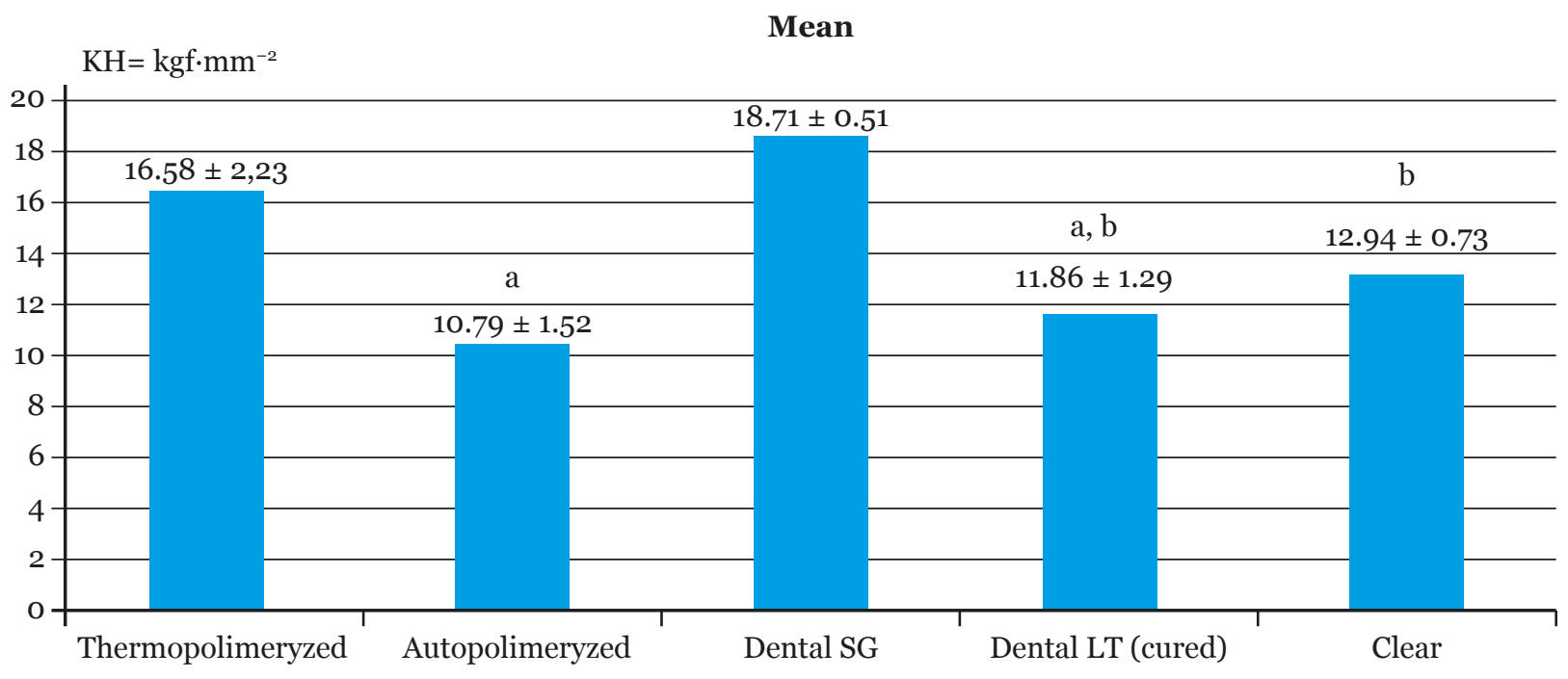

The results of the Knoop hardness among the resins for intraoral use showed the mean value of the Thermo polymerized, Autopolymerized, Dental SG and Dental LT are [16.58], [10.79], [18.71], [11.86], respectively. Despite the Clear resin not being used for intraoral use, considering the Knoop Hardness, its mean value [12.94] is comparable with the resins used intraorally, with its $\mathrm{KH}$ being significantly higher than the autopolymerized resin.

The SG resin mean value is the highest, being significantly different than all others. On the other hand, the lowest mean value is in the autopolymerized resins' samples.

\section{RESINS DIFFERENCE RELATED TO THE CURE}

Considering the resin recommended for intraoral long-term use, Dental LT, the Knoop hardness difference of post-processing light curing was evaluated. There was a non-post-cured and a post-cured group. They were compared with the thermo and autopolymerized resins. Table 7 shows the comparative analysis summary; Table 8 shows the data of the ANOVA test, and Table 9 the result of the Tukey's test for the same resins. Graph 2 shows the Knoop hardness mean value of each.

TABLE 7 | Summary Statistical Analysis of the resins - Cure Type.

\begin{tabular}{c|c|c|c|c|c} 
& Thermo polymerized M1 & Autopolymerized M2 & Dental LT (cured) M3 & Dental LT (non-cured) M4 & TOTAL \\
\hline$N$ & 15 & 15 & 15 & 15 & 60 \\
\hline$\sum x$ & 248.6 & 161.8 & 177.9 & 79.0 & 11.1367 \\
\hline Mean & 16.5733 & 10.7867 & 11.86 & 5.3267 & 426.67 \\
\hline$\sum \times 2$ & 4190.24 & 1777.82 & 2133.37 & 0.0764 & 18.4166 \\
\hline Variance & 5.0078 & 2.3241 & 1.6769 & 0.2764 & 4.2915 \\
\hline Std. Dev & 2.2378 & 1.5245 & 1.2949 & 0.0714 & 0.554 \\
\hline Std. Err. & 0.5778 & 0.3936 & 0.3344 & 0
\end{tabular}


TABLE 8 | ANOVA's test Data Summary of the resins, considering its cure type.

\begin{tabular}{l|c|c|c|c|c|}
\multicolumn{5}{|c|}{ ANOVA Summary } \\
\hline Source & SS & df & MS & F \\
\hline Treatment (between groups) & 959.3873 & 3 & 319.7958 & 140.8 & $<.0001$ \\
\hline Error & 127.192 & 56 & 2.2713 & \\
\hline Total & 1086.5793 & 59 & & \\
\hline
\end{tabular}

TABLE 9 | Tukey`s test results, considering resin`s cure type.

Tukey's HSD test

$\operatorname{HSD}[.05]=1.46 ; \mathrm{HSD}[.01]=1.8$

\begin{tabular}{l|l}
\hline M1vs M2 & $P<.01$ \\
\hline M1 vs M3 & $P<.01$ \\
\hline M1 vs M4 & $P<.01$ \\
\hline$M 2$ vs M3 & nonsignificant \\
\hline M2 vs M4 & $P<.01$ \\
\hline M3 vs M4 & $P<.01$
\end{tabular}

M1 = Thermo polymerized; M2 = Auto polymerized; M3= Dental LT (cured); M4= Dental LT $($ not cured)

$\mathrm{HSD}=$ the absolute [unsigned] difference between any two sample means required for significance at the designed level. HSD[.05] for the .05 level; HSD[.01] for the .01 level.

GRAPH 2 | KH mean values of the resins, considering its cure type, standard deviation and significance (groups identified by the same letter there was nonsignificant: (a) - autopolimerized and dental LT (cured) and (b) - dental LT (cured) and Clear).

$\mathrm{KH}=\mathrm{kgf} \cdot \mathrm{mm}^{-2}$

\section{Mean}

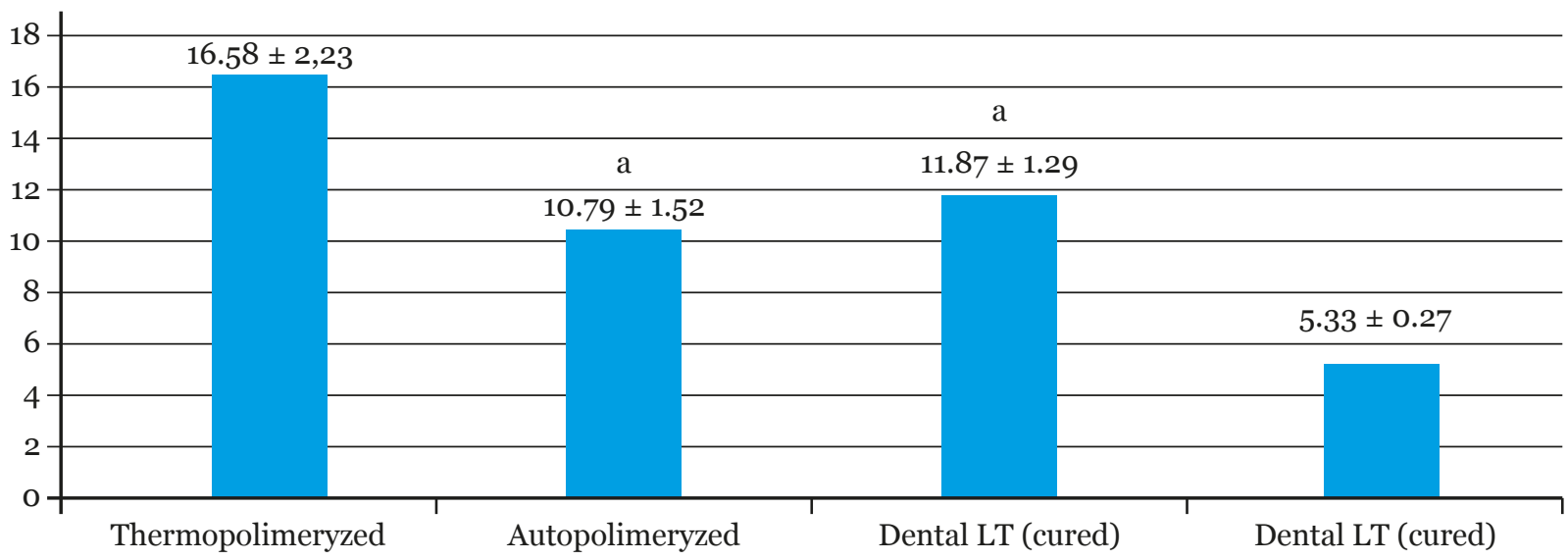


The results of the Knoop hardness when comparing the resins, considering the postprocessing cure, showed the mean value of the Thermopolymerized, Autopolymerized, Dental LT (cured) and Dental LT (not cured) are [16.58], [10.79], [11.86], and [5.3267], respectively. Significant differences were found between the types of resin, except between autopolymerized and Dental LT (cured) resin. The absence of the post-curing process reduced by more than $55 \%$ of the Knoop Hardness of the material. Proper resin post-curing is highly recommended by the manufacturer.

\section{DISCUSSION}

The hardness of the materials is important data for clinicians to understand its intraoral behavior. Thermopolymerized resins have been considered the gold standard of the acrylic resins since they, when correctly handled, present high material cure and high $\mathrm{KH}$ values. Clinically, they can be interpreted as a stable and wear resistant material, the autopolymerized resin usually has a lower $\mathrm{KH}$ value due to the different cure degree efficiency and the possibility of porosities during the manipulation of the material, even so, its $\mathrm{KH}$ value is pretty acceptable for manufacturing intraoral appliances. ${ }^{12}$

Based on the $\mathrm{KH}$ results of this research, when considering the new material, the SG resin showed higher $\mathrm{KH}$ than thermopolymerized resin, being the hardest material of these samples, the SG resin indication is to manufacture surgical guide appliances and the material hardness must keep the accuracy and reliability for the guidance. ${ }^{13}$

The Dental LT and Clear resin presents hardness lower than Dental SG and thermopolymerized resins, but Clear resin has a significant higher $\mathrm{KH}$ value than autopolymerized resin, and the Dental LT KH value is similar to the autopolymerized resin, showing that all resins tested are potentially compatible with the intraoral use, considering the hardness aspect.
Despite the manufacturer indications of intraoral long-term use for the Dental LT resin, no studies have been published yet about the resin, except for our investigation study.

To follow the correct protocol for resin manufacture is indispensable,,$^{14,15,16}$ as shown in the different results of the Dental LT post cured and nonpost-cured resin. The values of the non-post-cured resins are much lower than the post-cured ones and all other resins, which could be interpreted as not recommended for intraoral use.

\section{CONCLUSION}

In conclusion, considering the hardness characteristics, printer resins are comparable with the established acrylic resins, when handled according to the manufacturer's recommendations. The absence of material post-processing reduce significantly the hardness of the material.

As their hardness is compatible for intraoral use, the clinical indications and other mechanical characteristics must be considered when choosing the best resin for each case.

\section{ACKNOWLEDGMENT}

The first author would like to acknowledge CAPES (Coordenação de Aperfeiçoamento de Pessoal de Nivel Superior) for the scholarships, and the second and third authors would like to acknowledge The Foundation for the Scientific and Technological Development of Dentistry (FUNDECTO).

\section{COMPLIANCE WITH ETHICAL STANDARDS}

Conflict of Interest: All the authors declare no conflict of interest.

Funding: The study was supported by the Department Dental Prothesis and Department of Dental Materials at the School of Dentistry, University of São Paulo 
Ethical approval: This article does not contain any studies with human participants or animals performed by any of the authors.

Informed consent: For this type of study, formal consent is not required.

\section{REFERENCES}

1. Revilla-León M, Ozcan M. Additive Manufacturing technologies used for processing polymers: current status and potential application in Prosthetic Dentistry. J Prosthodont. 2018;28(2):1-13. doi: 10.1111/jopr.12801.

2. Schweiger J, Stumbaum J, Edelhoff D, Guth JF. Systematics and concepts for the digital production of complete dentures: risks and opportunities. Int J Comput Dent. 2018;21(1):41-56.

3. Bhargav A, Sanjairaj C, Rosa V, Feng LW, Fuh YhJ. Applications of additive manufacturing in dentistry: a review. $\mathrm{J}$ Biomed Mater Res B Appl Biomater. 2018;106(5):2058-2064. doi: 10.1002/jbm.b.33961.

4. Kawala M, Smardz J, Adamczyk L, Grychowska N, Wieckiewicz M. Selected applications for current polymers in prosthetic dentistry - state of the art. Curr Med Chem. 2018;25:1-11.

5. Saisadan D, Manimaran P, Meenapriva PK. In vitro comparative evaluation of the mechanical properties of temporary restorative materials used in fixed partial denture. J Pharm Bioallied Sci. 2016;8(suppl 1):S105-S109. doi: 10.4103/0975-7406.191936.

6. Sivakumar I, Arunachalam KS, Saijan S, Ramaraju AV, Rao B, Kamaraj B. Incorporation of antimicrobial macromolecules in acrylic denture base resin: a research composition and update. J Prostodont. 2014;23(4):284-90. doi: 10.1111/jopr12105.
7. Formlabs [Internet]. Clear safety data sheet [cited 2019 Oct 25]. Available from: https://bit.ly/32OoAGp

8. Formlabs [Internet]. Dental LT clear safety data sheet [cited 2019 Oct 25]. Available from: https://bit.ly/2BFN8Zg

9. Formlabs [Internet]. Dental SG safety data sheet [cited 2019 Oct 25]. Available from: https://bit.ly/2JncTBD

10. Knoop F, Peters CG, Emerson WB. A sensitive pyramidaldiamond tool for indentation measurements. Research Paper RP1220. National Bureau of Standards, U.S. Dept. Commerce. 1939:211-40.

11. Goiato MC, Santos DM, Andreotti AM, Nobrega AS, Moreno A, Haddad MF, et al. Effect of Beverages and Mouthwashes on the Hardness of Polymers Used in Intraoral Prostheses. $\mathrm{J}$ of Prosthod. 2014;23:559-64.

12. Fernandes AU, Goiato MC, Santos DM. Effect of weathering and thickness on the superficial microhardness of acrylic resin and ocular button. Cont Lens Anterior Eye. 2009;32:283-87.

13. Kurzmann C, Janjić K, Shokoohi-Tabrizi H, Edelmayer M, Pensch M, Moritz A, et al. Evaluation of resins for stereolithographic 3D-printed surgical guides: the response of L929 cells and human gingival fibroblasts. Biomed Res Int. 2017;4057612.

14. Formlabs [Internet]. A guide to post-curing Formlabs resins [cited 20198 Oct 25]. Available from: https://bit.ly/32NnXjt

15. Washing settings [Internet]. Form wash time settings [cited 2019 Oct 25]. Available from: https://bit.ly/365PcYu

16. Voet VSD, Strating T, Schnelting GHM, Dijkstra P, Tietema $\mathrm{M}, \mathrm{Xu} \mathrm{J}$, et al. Biobased acrylate photocurable resin formulation for stereolithography $3 \mathrm{D}$ printing. ACS Omega. 2018;3(2):1403-8. 